\title{
Correction to: Climatic factors controlling stem growth of alien tree species at a mesic forest site: a multispecies approach
}

\author{
Nils Hoffmann ${ }^{1} \mathbb{D} \cdot$ Steffi Heinrichs ${ }^{1} \cdot$ Peter Schall ${ }^{1}$. Torsten Vor ${ }^{1}$
}

Published online: 7 August 2021

(c) The Author(s) 2021

\section{Correction to: \\ European Journal of Forest Research (2020) 139:915-934 https://doi.org/10.1007/s10342-020-01295-3}

The article "Climatic factors controlling stem growth of alien tree species at a mesic forest site: a multispecies approach", written by Nils Hoffmann, Steffi Heinrichs, Peter Schall and Torsten Vor, was originally published Online First without Open Access. After publication in volume 139, issue 6, page 915-934 the author decided to opt for Open Choice and to make the article an Open Access publication. Therefore, the copyright of the article has been changed to (C) The Author(s) 2020 and the article is forthwith distributed under the terms of the Creative Commons Attribution 4.0 International License, which permits use, sharing, adaptation, distribution and reproduction in any medium or format, as long as you give appropriate credit to the original author(s) and the source, provide a link to the Creative Commons licence and indicate if changes were made. The images or other third-party material in this article is included in the article's Creative Commons licence, unless indicated otherwise in a credit line to the material. If material is not included in the article's Creative Commons licence and your intended use is not permitted by statutory regulation or exceeds the permitted use, you will need to obtain permission directly from the copyright holder. To view a copy of this licence, visit http:// creativecommons.org/licenses/by/4.0. Open access funding enabled and organized by Projekt DEAL.

The original article has been corrected.

Open Access This article is licensed under a Creative Commons Attribution 4.0 International License, which permits use, sharing, adaptation, distribution and reproduction in any medium or format, as long as you give appropriate credit to the original author(s) and the source, provide a link to the Creative Commons licence, and indicate if changes were made. The images or other third party material in this article are included in the article's Creative Commons licence, unless indicated otherwise in a credit line to the material. If material is not included in the article's Creative Commons licence and your intended use is not permitted by statutory regulation or exceeds the permitted use, you will need to obtain permission directly from the copyright holder. To view a copy of this licence, visit http://creativecommons.org/licenses/by/4.0/.

Publisher's Note Springer Nature remains neutral with regard to jurisdictional claims in published maps and institutional affiliations.

The original article can be found online at https://doi.org/10.1007/ s10342-020-01295-3.

Nils Hoffmann

nhoffma@posteo.de

1 Department of Silviculture and Forest Ecology of the Temperate Zones, Faculty of Forest Sciences and Forest Ecology, University of Göttingen, Büsgenweg 1, 37077 Göttingen, Germany 